\title{
PENGARUH LINGKUNGAN KELUARGA DAN LINGKUNGAN SOSIAL TERHADAP KEPRIBADIAN DAN MINAT BERWIRAUSAHA MAHASISWA
}

\section{INFLUENCE OF FAMILY AND SOCIAL ENVIRONMENTAL SURVIVALS ON PERSONALITY AND INTEREST STUDENTS ENTREPRENEURS}

\author{
Sri Wahyu Lelly Hana Setyanti ${ }^{1}$, Dedikasi Herlambang ${ }^{2}$, Ema Desia Prajitiasari ${ }^{3}$ \\ ${ }^{123}$ Jurusan Manajemen Universitas Jember \\ Email:lelyhana.feb@unej.ac.id, dedikasi@gmail.com,ema.desia@yahoo.com
}

\begin{abstract}
ABSTRAK
Tujuan penelitian ini adalah untuk mengetahui pengaruh lingkungan keluarga, lingkungan sosial dengan mediasi kepribadian terhadap minat berwirausaha mahasiswa Universitas Jember. Fenomena penelitian ini adalah semakin meningkatnya minat mahasiswa untuk berwirausaha dengan adanya program kewirausahaan dari Universitas Jember seperti program mahasiswa wirausaha, pelatihan kewirausahaan. Teknik pengambilan sampel dalam penelitian ini menggunakan proporsional random sampling sebanyak 105 mahasiswa. Metode analisis data yang digunakan dalam penelitian ini adalah analisis jalur, untuk mengetahui pengaruh secara langsung dan tidak langsung dari masing-masing variabel. Hasil penelitian menunjukkan bahwa lingkungan keluarga dan lingkungan sosial berpengaruh melalui mediasi kepribadian terhadap minat berwirausaha mahasiswa.
\end{abstract}

Kata Kunci: lingkungan keluarga, lingkungan sosial, minat berwirausaha, kepribadian

\begin{abstract}
The purpose of this study is to determine the influence of family environment, social environment with the mediation of personality to entrepreneurship interests of students of Jember University. The phenomenon of this research is increasing the interest of students to entrepreneurship with the entrepreneurship program from Jember University such as entrepreneurship student program, entrepreneurship training. Sampling technique in this study using proportional random sampling of 105 students. Data analysis method used in this research is path analysis, to know the influence directly and indirectly from each variable. The results showed that the family environment and social environment influence through the mediation of personality towards student entrepreneurship interest.
\end{abstract}

Keywords: family environment, social environment, entrepreneurship interest, personality 


\section{PENDAHULUAN}

Universitas Jember sebagai salah satu perguruan tinggi di Indonesia sangat mendukung program pemerintah untuk mencetak wirausaha baru melalui berbagai program kegiatan diantaranya terbentuknya unit kegiatan mahasiswa wirausaha, program mahasiswa wirausaha dan berbagai bentuk pelatihan kewirausahaan. Tingginya minat mahasiswa Universitas Jember untuk berwirausaha diharapkan dapat menjadi bekal bagi mahasiswa setelah menyelesaikan pendidikan di Universitas Jember, serta dapat memutus mata rantai kemiskinan bagi diri dan keluarga mereka. Brown dan Brooks (1990:82) dalam Aprilianty (2013) mendefinisikan minat sebagai suatu yang membangkitkan atau memegang perhatian atau rasa ingin tahu seseorang. Indikasi ketertarikan diantaranya apa yang seseorang ingin lakukan atau apa yang mereka nikmati atau sukai.

Stewart et al. (1998) menjelaskan bahwa minat berwirausaha dapat dipengaruhi oleh faktor internal (sifat personal, sikap, kemauan, dan kemapuan), faktor eksternal (lingkungan keluarga, lingkungan sosial ekonomi, dll), serta faktor kontekstual (dukungan pendidikan, pengalaman, dan pembekalan kewirausahaan). Tjahjono dan Ardi (2008) juga menjelaskan bahwa seseorang memutuskan berwirausaha dipengaruhi beberapa faktor diantaranya, faktor internal (kepribadian, persepsi, motivasi, dan pembelajaran), dan faktor ekternal (lingkungan keluarga, teman, dan tetangga). Penelitian Purwinarti (2006) ,Winardi (2011) dan Muladi (2011) menunjukkan bahwa salah satu faktor pendorong seseorang berwirausaha adalah the parental refugee, yaitu lingkungan keluarga dan lingkungan sosial memberikan kontribusi yang tinggi terhadap minat berwirausaha.

Sesuai dengan penelitian yang dilakukan oleh Moppangga (2014) bahwa dukungan sosial dari orang yang dipercaya (orang tua, teman sebaya, ataupun orang lain) sangat efektif untuk meningkatkan kepribadian seseorang yang berupa kepercayaan diri. Peneliti menemukan teori determinisme-resiprokal (reciprocal-determinism), yaitu kepribadian seseorang dapat mempengaruhi, dan dipengaruhi oleh situasi khusus dimana seseorang tinggal, cara orang tua memperlakukan anak, dan pengaruh teman sebaya, sehingga kepribadian seseorang tidak semata-mata dipengaruhi oleh faktor genetis belaka (Wade dan Tavris, 2007:213). Hasil penelitian Alma (2007) juga menunjukkan bahwa salah satu faktor yang mendorong mahasiswa berwirausaha adalah kepribadian. 
Oleh karena itu dalam berwirausaha diperlukan kepribadian yang baik sehingga menciptakan kepribadian yang produktif yang mendukung dalam menjalankan usaha.

\section{Rumusan Masalah}

Berdasarkan pada pemaparan latar belakang, maka rumusan masalah dalam penelitian ini diantarnya, yaitu:

1. Apakah lingkungan keluarga berpengaruh terhadap kepribadian mahasiswa?

2. Apakah lingkungan sosial berpengaruh terhadap kepribadian mahasiswa?

3. Apakah lingkungan keluarga berpengaruh terhadap minat berwirausaha mahasiswa?

4. Apakah lingkungan sosial berpengaruh terhadap minat berwirausaha mahasiswa?

5. Apakah kepribadian berpengaruh terhadap minat berwirausaha mahasiswa?

\section{METODE PENELITIAN}

\section{Analisis Statistik}

Analisis yang digunakan menggunakan analisis jalur (path analysis) yang bertujuan untuk menganalisis hubungan kausal antar variabel dan menguji hipotesis secara sistematis yaitu analisis jalur (path analysis) dengan dibantu software SPSS. Pengaruh kausal antarvariabel dan kedudukan masing-masing variabel dalam jalur baik secara langsung maupun tidak langsung akan dilakukan estimasi dengan path analysis.

Model analisis jalur yang digunakan dalam penelitian ini dapat diformulasikan dalam persamaan berikut:

$$
\begin{array}{ll}
\mathrm{Y} & =\beta \mathrm{Y}_{\mathrm{i}} \mathrm{X}_{1 \mathrm{i}+} \beta \mathrm{Y}_{\mathrm{i}} \mathrm{X}_{2 \mathrm{i}}+\varepsilon_{1 \mathrm{i}}(\text { Persamaan 1) } \\
\mathrm{Z} & =\beta \mathrm{Z}_{\mathrm{i}} \mathrm{X}_{1 \mathrm{i}}+\beta \mathrm{Z}_{\mathrm{i}} \mathrm{X}_{2 \mathrm{i}}+\beta \mathrm{Z}_{\mathrm{i}} \mathrm{Y}_{\mathrm{i}}+\varepsilon_{2 \mathrm{i}}(\text { Persamaan 2) }
\end{array}
$$

Dimana:

$$
\begin{aligned}
& X 1=\text { Lingkungan Keluarga } \\
& X 2=\text { Lingkungan Sosial } \\
& Z=\text { Kepribadian } \\
& Y=\text { Minat Berwirausaha }
\end{aligned}
$$

Hipotesis Penelitian

H1 : Lingkungan keluarga berpengaruh terhadap kepribadian mahasiswa

H2 : Lingkungan sosial berpengaruh terhadap kepribadian mahasiswa

H3 : Lingkungan keluarega berpengaruh terhadap minat berwirausaha mahasiswa

H4 : Lingkungan sosial berpengaruh terhadap minat berwirausaha mahasiswa

H5 : Kepribadian berpengaruh terhadap minat berwirausaha mahasiswa 


\section{Populasi dan Sampel Penelitian}

Populasi penelitian ini adalah seluruh mahasiswa Bidik Misi angkatan 2012 dengan jumlah 1050 orang mahasiswa yang tersebar di 15 fakultas dan program studi yang ada di Universitas Jember. Pengambilan sampel menggunakan teknik proporsional random sampling, yaitu pengambilan sampel secara proporsi dilakukan dengan mengambil subyek dari setiap wilayah ditentukan seimbang dengan banyaknya subyek dalam masing-masing strata. Penelitian ini menggunakan besaran $10 \%$ dari populasi mahasiswa Bidik Misi untuk menentukan jumlah sampel, dan diambil secara proporsional yaitu sebanyak 105 mahasiswa.

\section{Definisi Operasional Variabel}

Variabel penelitian ini terdiri dari 2 (dua ) variabel bebas, satu variabel intervening dan satu variabel tergantung.

1. Variabel terikat (Y) yaitu minat berwirausaha.

adalah kemauan yang muncul dari dalam diri mahasiswa untuk memikirkan ide bisnis dan menjalankan ide bisnis tersebut.

2. Variabel lingkungan keluarga $\left(\mathrm{X}_{1}\right)$ adalah suatu lingkungan pertama dan yang utama sebagai tempat seseorang membentuk kepribadiannya, serta berproses mempelajari kehidupan bermasyarakat.

3. Variabel lingkungan sosial $\left(\mathrm{X}_{2}\right)$ adalah suatu lingkungan yang mencakup teman sebaya, tetangga, para tokoh masyarakat yang berada di sekitar mahasiswa tinggal dan bersosialisasi.

4. Variabel intervening kepribadian $(Z)$ adalah sifat, sikap dan perilaku yang melekat pada mahasiswa untuk mewujudkan gagasan inovatif ke dalam dunia usaha yang nyata dan dapat mengembangkannya dengan tangguh.

\section{Pengolahan data}

Data variabel motivasi belajar di bagi dalam 4 kategori sebelum data diolah menggunakan program SPPS. Kategori ini didasarkan pada penghitungan skala Likert dan jumlah butir soal 21 soal. 


\section{HASIL DAN PEMBAHASAN}

\section{Analisis Karakteristik Responden}

Berikut ini adalah analisis karakteristik responden

Tabel 1 Karakteristik Responden

\begin{tabular}{|c|c|c|c|}
\hline \multicolumn{2}{|c|}{ Karakteristik Responden } & \multirow{2}{*}{$\begin{array}{c}\begin{array}{l}\text { Frekuensi } \\
\text { (orang) }\end{array} \\
34 \\
71\end{array}$} & \multirow{2}{*}{$\begin{array}{l}\text { Persentase } \\
(\%)\end{array}$} \\
\hline 1. Jenis kelamin & $\begin{array}{l}\text { a. Laki-laki } \\
\text { b. Perempuan }\end{array}$ & & \\
\hline & Jumlah & 105 & 100 \\
\hline \multirow[t]{2}{*}{ 2. Umur } & $\begin{array}{l}\text { a. } 21 \text { tahun } \\
\text { b. } 22 \text { tahun } \\
\text { c. } 23 \text { tahun }\end{array}$ & $\begin{array}{l}35 \\
57 \\
15\end{array}$ & $\begin{array}{l}33,33 \\
54,29 \\
12,38\end{array}$ \\
\hline & Jumlah & 105 & 100 \\
\hline \multirow[t]{2}{*}{$\begin{array}{l}\text { 3. Pengalaman } \\
\text { Bisnis }\end{array}$} & $\begin{array}{l}\text { a. Online Shop } \\
\text { b. Guru privat } \\
\text { c. Bisnis pulsa } \\
\text { d. Bisnis } \\
\text { Makanan } \\
\text { e. Lain-lain }\end{array}$ & $\begin{array}{l}27 \\
24 \\
18 \\
16 \\
20\end{array}$ & $\begin{array}{l}25,71 \\
22,86 \\
17,14 \\
14,24 \\
19,05\end{array}$ \\
\hline & Jumlah & 105 & 100 \\
\hline \multirow[t]{2}{*}{$\begin{array}{l}\text { 4. Pekerjaan } \\
\text { Orang tua }\end{array}$} & $\begin{array}{l}\text { a. Wiraswasta } \\
\text { b. Pegawai } \\
\quad \text { Swasta } \\
\text { c. Petani } \\
\text { d. Lain-lain }\end{array}$ & $\begin{array}{l}38 \\
16 \\
29 \\
22\end{array}$ & $\begin{array}{l}36,19 \\
15,24 \\
27,62 \\
20,95\end{array}$ \\
\hline & Jumlah & 105 & 100 \\
\hline
\end{tabular}

Sumber : data diolah, 2017

Analisis jalur (path analysis) digunakan untuk menganalisis hubungan kasual antar variabel dimana variabel-variabel bebas mempengaruhi variabel tergantung, baik secara langsung maupun tidak langsung, melalui satu atau lebih perantara. Berdasarkan uji analisa jalur model diagram analisis jalur beserta koefisien jalurnya sebagai berikut :

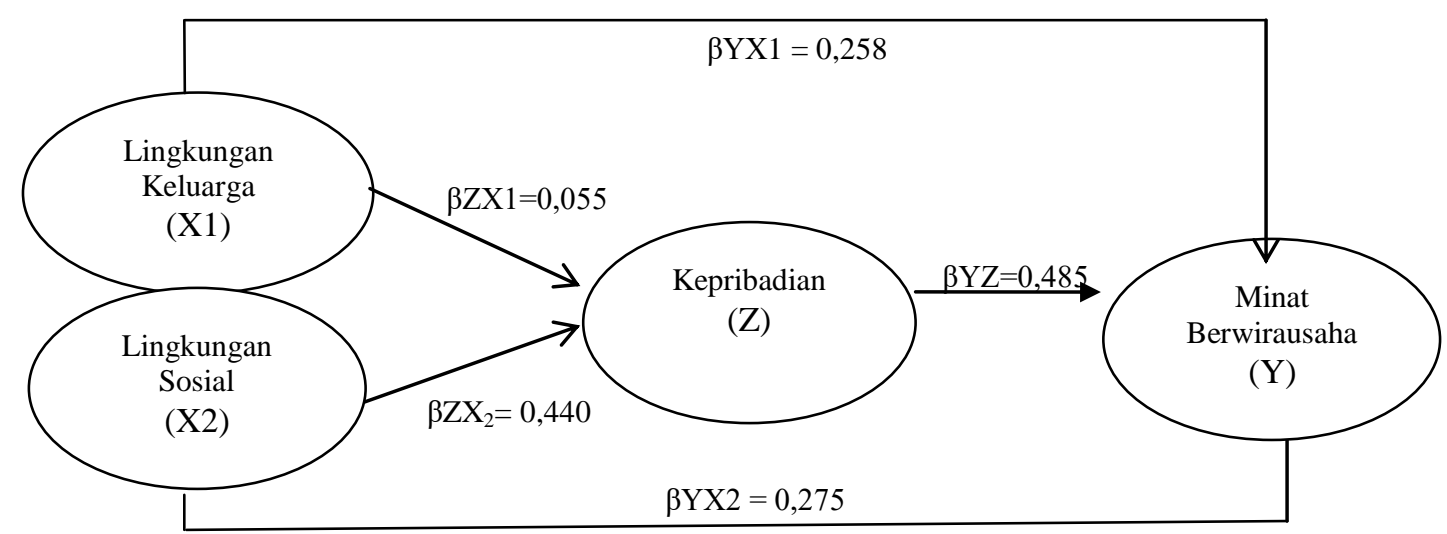




$$
\begin{aligned}
& Z=0,055 Z X 1+0,440 Z X 2+\varepsilon 1 Z=0,055 Z X 1+0,440 Z X 2+\varepsilon 1 \\
& Y=0,258 \mathrm{YX}_{1}+0,275 \mathrm{YX}_{2}+0,485 \mathrm{YZ}+\varepsilon_{2}
\end{aligned}
$$

Tabel 2 Nilai Koefisien Jalur

\begin{tabular}{ccccccc}
\hline No & $\begin{array}{c}\text { Variabel } \\
\text { Bebas }\end{array}$ & $\begin{array}{c}\text { Variabel } \\
\text { Terikat }\end{array}$ & Beta & t-hitung & p-value & Keterangan \\
\hline 1 & $\mathrm{X}_{1}$ & $\mathrm{Z}$ & 0,055 & 2,407 & 0,015 & Signifikan \\
2 & $\mathrm{X}_{2}$ & $\mathrm{Z}$ & 0,440 & 2,847 & 0,005 & Signifikan \\
3 & $\mathrm{X}_{1}$ & $\mathrm{Y}$ & 0,258 & 1,744 & 0,024 & Signifikan \\
4 & $\mathrm{X}_{2}$ & $\mathrm{Y}$ & 0,275 & 2,776 & 0,018 & Signifikan \\
5 & $\mathrm{Z}$ & $\mathrm{Y}$ & 0,485 & 4,496 & 0,000 & Signifikan \\
\hline
\end{tabular}

Sumber : Data diolah, 2017

Hasil nilai koefisien analisis jalur menunjukkan bahwa model pengaruh variabel lingkungan keluarga (X1), lingkungan sosial (X2) dengan mediasi kepribadian (Z) memiliki pengaruh positif terhadap minat berwirausaha mahasiswa.

\section{Pengaruh Lingkungan Keluarga terhadap Kepribadian Mahasiswa}

Hasil analisis jalur menunjukkan bahwa lingkungan keluarga berpengaruh signifikan terhadap minat berwirausaha mahasiswa sebesar 25,8\%. Hasil tersebut menunjukkan bahwa hipotesis pertama dari penelitian ini diterima, yakni lingkungan keluarga berpengaruh signifikan terhadap kepribadian mahasiswa Penelitian ini mendukung penelitian yang dilakukan oleh Aprilianty (2013) yang menunjukkan bahwa lingkungan keluarga berpengaruh positif dan signifikan terhadap minat berwirausaha seseorang. Penelitian terdahulu yang dilakukan oleh Koranti (2013) juga menunjukkan bahwa lingkungan keluarga berpengaruh positif dan signifikan terhadap minat berwirausaha. Hal ini terlihat dari adanya orang tua mahasiswa yang berprofesi sebagai wirausahawan dan dukungan dari keluarga menjadi stimulus atau pengaruh bagi mahasiswa untuk menjadi wirausahawan.

\section{Pengaruh Lingkungan Sosial terhadap Kepribadian Mahasiswa}

Variabel lingkungan sosial berpengaruh signifikan terhadap kepribadian mahasiswa yaitu sebesar 44\%. Hasil tersebut menunjukkan bahwa hipotesis kedua dari penelitian ini diterima, yakni lingkungan keluarga berpengaruh signifikan terhadap kepribadian mahasiswa. Hasil penelitian ini mendukung penelitian terdahulu yang dilakukan oleh Afiatin dan Andayani (1998) yang menyatakan bahwa dukungan sosial dari orang yang dipercaya (orang tua, teman sebaya, orang lain) sangat efektif untuk 
meningkatkan kepribadian seseorang yang berupa kepercayaan diri. Penelitian ini juga menunjang teori determinisme-resiprokal (reciprocal-determinism) yang dinyatakan oleh Wade dan Tavris (2007:213), yaitu kepribadian seseorang dapat mempengaruhi, dan dipengaruhi oleh situasi khusus dimana seseorang tinggal, cara orang tua memperlakukan anak, dan pengaruh teman sebaya, sehingga kepribadian seseorang tidak semata-mata dipengaruhi oleh faktor genetis belaka.

\section{Pengaruh Lingkungan Keluarga terhadap Minat Berwirausaha Mahasiswa}

Variabel lingkungan keluarga berpengaruh signifikan terhadap minat berwirausaha mahasiswa sebesar $25,8 \%$. Hasil tersebut menunjukkan bahwa hipotesis ketiga dari penelitian ini diterima, yakni lingkungan keluarga berpengaruh signifikan terhadap minat berwirausaha mahasiswa. Hasil penelitian ini mendukung penelitian terdahulu yang dilakukan oleh Aprilianty (2013) yang menunjukkan bahwa lingkungan keluarga berpengaruh positif dan signifikan terhadap minat berwirausaha seseorang. Hal ini terlihat dari adanya orang tua mahasiswa yang berprofesi sebagai wirausahawan sehingga mereka ingin melanjutkan jejak orang tuanya, pengetahuan orang tua tentang dunia wirausaha, pola pikir orang tua bahwa menjadi wirausahawan adalah profesi yang mulia, dan yang terpenting adanya dukungan dari keluarga untuk menjadi wirausahawan bagi mahasiswa.

\section{Pengaruh Lingkungan Sosial terhadap Minat Berwirausaha Mahasiswa}

Hasil dari penelitian ini menjelaskan bahwa minat berwirausaha mahasiswa sebesar 25,8\% dipengaruhi oleh lingkungan sosial. Hasil tersebut menunjukkan bahwa hipotesis keempat dari penelitian ini diterima, yakni lingkungan sosial berpengaruh signifikan terhadap minat berwirausaha mahasiswa. Minat berwirausaha mahasiswa salah satunya dipengaruhi oleh lingkungan sosial. Hal ini terjadi karena mahasiswa melihat kesuksesan temannya yang lebih dahulu berwirausaha, mereka tergabung dalam komunitas bisnis atau organisasi kewirausahaan, adanya mentor bisnis yang siap mendampingi mereka dalam memulai berwirausaha, adanya kegiatan-kegiatan yang merangsang minat berwirausaha seperti Pekan Kreativitas Mahasiswa, Pekan Mahasiswa Wirausaha, dan lomba penyusunan business plan lainnya yang diadakan oleh Universitas Jember atau pihak swasta. 


\section{Pengaruh Kepribadian terhadap Minat Berwirausaha Mahasiswa}

Hasil analisis jalur menunjukkan kepribadian berpengaruh signifikan terhadap minat berwirausaha mahasiswa yaitu 48,5\%. Hasil tersebut menunjukkan bahwa hipotesis kelima dari penelitian ini diterima, yakni kepribadian berpengaruh signifikan terhadap minat berwirausaha mahasiswa. Hasil dari penelitian ini mendukung beberapa penelitian terdahulu yang telah dilakukan oleh Aprilianty (2013) dan Koranti (2013). Kedua peneliti tersebut menjelaskan dalam penelitiannya bahwa kepribadian berpengaruh positif dan signifikan terhadap minat berwirausaha seseorang. Anoraga dan Sudantoko (2002:10) menjelaskan bahwa pada pekerjaan-pekerjaan tertentu, sifat-sifat kepribadian seseorang sangat berhubungan dengan kesuksesan dalam bekerja.Variabel kepribadian menjadi variabel paling berpengaruh terhadap minat berwirausaha mahasiswa. Hal ini menunjukkan bahwa kepribadian mahasiswa yang kreatif, inovatif, berani menanggung risiko, mandiri, percaya diri sesuai dengan kepribadian yang dimiliki oleh para wirausahawan.

\section{KESIMPULAN DAN SARAN}

Lingkungan keluarga, lingkungan sosial dan kepribadian turut berpengaruh terhadap minat berwirausaha mahasiswa. Lingkungan keluarga dan lingkungan sosial dapat memberikan dukungan terhadap mahasiswa agar minat berwirausaha mahasiswa dapat terus ditingkatkan. Variabel kepribadian menunjukkan pengaruh lebih besar terhadap minat berwirausaha mahasiswa. Ini menunjukkan bahwa kepribadian wirausahawan yang telah dimiliki akan menjadi bekal utama dalam setiap profesi yang hendak digeluti nantinya.

\section{REFERENSI}

Afiatin, Tina dan Budi Andayani. 1998. Peningkatan Kepercayaan Diri Remaja Penganggur Melalui Kelompok Dukungan Sosial. Jurnal Psikologi, Yogyakarta: Universitas Gajah Mada, No. (2):35-46.

Alma, B. 2007. Kewirausahaan. Alfabeta. Bandung.

Anoraga, Pandji dan Djoko Sudantoko. 2002. Koperasi, Kewirausahaan, dan Usaha Kecil. Jakarta: Rineka Cipta.

Aprilianty, Eka. 2013. Pengaruh Kepribadian Wirausaha, Pengetahuan Kewirausahaan, dan Lingkungan Terhadap Minat Berwirausaha Siswa SMK. Jurnal Pendidikan Vokasi, Yogyakarta: Universitas Negeri Yogyakarta. Vol 2(3):311-324. 
Koranti, Komsi. 2013. Analisis Pengaruh Faktor Eksternal dan Internal Terhadap Minat Berwirausaha. Jurnal PESAT, Bandung: Jurusan Manajemen, Fakultas Ekonomi, Universitas Gunadarma.

Mopangga, Hermin. 2014. Faktor Determinan Minat Wirausaha Mahasiswa Fakultas Ekonomi dan Bisnis Universitas Negeri Gorontalo. Jurnal Trikonomika, Gorontalo: Fakultas Ekonomi dan Bisnis, Universitas Negeri Gorontalo. 13(1):78-90.

Muladi, W. 2011. Pembelajaran kewirausahaan dan minat wirausaha lulusan SMK. Jurnal Ekspansi, 6, 35-39 . Muladi, W. 2011. Pembelajaran kewirausahaan dan minat wirausaha lulusan SMK. Jurnal Ekspansi, 6, 35-39 .

Purwinarti, T. 2006. Faktor pendorong minat berwirausaha (studi lapangan terhadap Politeknik Negeri Jakarta . Jurnal Penelitian Ekonomi dan Bisnis, 5, 39-46.

Stewart, W.H., Watson, W.E., Carland, J.C. \& Carland, J.W. 1998. A proclivity for entrepreneurship: A comparison of entrepreneurs, small business owners, and corporate managers. Journal of Business Venturing, 14, 189-214

Tjahjono, H.K., \& Ardi, H. 2008. Kajian niat mahasiswa manajemen Universitas Muhammadiyah Yogyakarta untuk menjadi wirausaha. Utilitas Jurnal Manajemen dan Bisnis, 16, 46-63

Wade, Carole dan Carol Tavris. 2007. Psikologi Edisi Kesembilan Jilid 2. Jakarta: Erlangga 